\title{
Since When Do Prophets Write?
}

\section{Nissinen, Martti}

Peeters

2014

Nissinen , M 2014 , Since When Do Prophets Write? in K De Troyer , T M Law \& M Liljeström (eds), In the Footsteps of Sherlock Holmes : Studies in the Biblical Text in Honour of Anneli Aejmelaeus . Conributions to Biblical Exegesis and Theology, vol. 72 , Peeters, pÿLeuven , pp. 585606 .

http://hdl.handle.net/10138/325485

draft

Downloaded from Helda, University of Helsinki institutional repository.

This is an electronic reprint of the original article.

This reprint may differ from the original in pagination and typographic detail.

Please cite the original version. 
SECTION FIVE

HEBREW BIBLE AND DEAD SEA SCROLLS 


\title{
SINCE WHEN DO PROPHETS WRITE?
}

\author{
Martti NisSINEN
}

\author{
WRITING PROPHETS?
}

Several generations of Bible students have learned in their textbooks that there are two kinds of prophets in the Hebrew Bible: the 'writing prophets' responsible for the prophetic books, at least in embryonic form, and other prophets not associated with any kind of writing activity. The former group is often given the title 'classical prophets', implying an elevated status among the biblical prophets, while the latter group, consisting of the so-called 'pre-classical' prophets and the somewhat amorphous bunch of 'cult prophets', 'court prophets' and the kind, has enjoyed a considerable lesser degree of admiration. ${ }^{1}$ While still well and alive even in some quite recent textbooks and introductions to the Hebrew Bible, the distinction between writing and non-writing prophets has eroded significantly in critical scholarship during the past decades. This development has taken place hand in hand with the growing conviction that the biblical prophetic books are the product of a long scribal process which distances the prophetic figures, however highly appreciated, from the textual product bearing their names. ${ }^{2}$ This development, however, has not solved the question

1 See, e.g., Matthijs J. de Jong, 'Biblical Prophecy - A Scribal Enterprise: The Old Testament Prophecy of Unconditional Judgement Considered as a Literary Phenomenon', VT 61 (2011), pp. 39-70, esp. 42-44.

2 For recent contributions, see Jean-Daniel Macchi and Thomas Römer, 'La formation des livres prophétiques: enjeux et débats', in Jean-Daniel Macchi, Christophe Nihan, Thomas Römer, and Jan Rückl (eds.), Les recueils prophétiques de la Bible: Origines, milieux, et contexte proche-oriental (Le Monde de la Bible 64; Geneva, 2012), pp. 9-27; Reinhard G. Kratz, 'Probleme der Prophetenforschung', in idem, Prophetenstudien: Kleine Schriften II (FAT 74; Tübingen, 2011), pp. 3-17; Diana Edelman, 'From Prophets to Prophetic Books', in Diana V. Edelman and Ehud Ben Zvi (eds.), The Production of Prophecy: Constructing Prophecy and Prophets in Yehud (Bible World; London, 2009), pp. 29-54; Ehud Ben Zvi, 'The Concept of Prophetic Books and Its Historical Setting', ibid., pp. 73-95; Karel van der Toorn, Scribal Culture and the Making of the Hebrew Bible (Cambridge MA, 2007) pp. 173-232; Michael H. Floyd, 'The Production of Prophetic Books in the Early Second Temple Period', in Michael H. Floyd and Robert D. Haak (eds.), Prophets, Prophecy, and Prophetic Texts in Second Temple Judaism (LHBOTS 427; London, 2006), pp. 276-297; Konrad Schmid, 'Hintere Propheten (Nebiim)', in Jan Christian Gertz (ed.), Grundinformation Altes Testament: Eine Einführung 
of whether 'writing prophets' actually existed; that is, whether writing can be seen as belonging to prophetic activity, independently from the issue of the authorship of the biblical prophetic books. In other words, is there is a historical grain of truth to the idea of 'writing prophets'?

Already in ancient texts, the image of a prophet is associated with production of texts, and the idea of a prophetic 'book', or scroll, dates back to the Hebrew Bible itself. The act of writing as such is a prerequisite of the production of prophetic books, hence the question remains whether the sources available to us - whether biblical or not - actually imply that prophets were involved in scribal activities leading to the transformation of oral transmission of divine messages into written and/or literary prophecy. ${ }^{3}$

The title of this essay was originally formulated in the past tense: 'Since when did prophets write?'; however, who would be able to answer such a question on the basis of the very fragmented source material we have at our disposal? The title in the present tense, 'Since when do prophets write?', implies the continuation, '... in the sources available to us', and this is what makes the question answerable. In this essay, dedicated with much pleasure to Anneli Aejmelaeus, my dear colleague in Helsinki, ${ }^{4}$ I will confine myself to the simple question: Is there evidence of 'writing prophets' in the ancient Near Eastern sources, including the Hebrew Bible, and if prophets are not caught in the very act of writing, are they otherwise involved in production of texts? Larger issues such as sociology of literacy, the authorship of the biblical prophetic books, the oral/written distinction, and the textualization of prophecy, I leave to be discussed in another contexts.

in Literatur, Religion und Geschichte des Alten Testaments (UTB 2745; Göttingen, 2006), pp. 303-401; Martti Nissinen, 'How Prophecy Became Literature', SJOT 19 (2005), pp. $153-172$.

3 For the distinction of written prophecy (prophetic oracles written down and sometimes compiled in collections) and literary prophecy (reapplication and recontextualizarion of prophetic oracles and creation of prophetic literature), see Armin Lange, 'Literary Prophecy and Oracle Collection: A Comparison between Judah and Greece in Persian Times', in Floyd and Haak (eds.), Prophets, Prophecy, and Prophetic Texts in Second Temple Judaism, pp. 248-275.

${ }^{4}$ Anneli Aejmelaeus has herself contributed to the issue of the textual evidence of the emergence of the prophetic books, especially Jeremiah; see 'Nebuchadnezzar, My Servant: Redaction History and Textual Development in Jer 27', in Florentino García Martínez and Marc Vervenne (eds.), Interpreting Translation: Studies on the LXX and Ezekiel in Honour of Johan Lust (BETL 192; Leuven, 2005), pp. 1-18; 'Jeremiah at the Turning-Point of History: The Function of Jer xxv 1-14 in the Book of Jeremiah', VT 52 (2002), pp. 459-482. 


\section{ANCIENT NEAR EAST}

In Neo-Assyrian texts, prophecy appears as an oral phenomenon. The Neo-Assyrian technical term for prophesying is the verb ragāmu, which means 'to shout', 'to proclaim', expressly referring to oral activity; consequently, the Neo-Assyrian prophets bear the designation raggimu (male) or raggintu (female). ${ }^{5}$ The colophons of the prophetic oracles regularly present them as coming 'from the mouth' ( $\check{s} a p \hat{\imath}$ or $i s s u p \hat{\imath})$ of the prophets mentioned by name. ${ }^{6}$

In some inscriptions, prophecies (together with celestial omens) are referred to as šipir mahhê, literally 'messages ("sendings") of prophets,' also equated with našparti ilāni u Ištar 'messages of the gods and Ištar':

'Favorable omens in the sky and on earth came to me. Oracles of prophets (šipir mahhê), messages of the gods and Ištar (našparti ilāni u Ištar), were constantly sent to me and they encouraged my heart'?

The words šipru and našpartu both mean 'message', and in the Assyrian royal inscriptions, they are used specifically to mean divine messages. ${ }^{8}$ One can plausibly think the expression šipir mahhê to refer to the entire prophetic performance and the subsequent process of communication that eventually may (but need not) have included writing the oracle down; this was demonstrably the case on occasion of Esarhaddon's ascending the throne.

5 Verb ragāmu: SAA 96 r. 12; SAA 910 s. 2 (?); SAA 10 352:23; SAA 13 37:10; noun raggimu/raggintu: SAA 93.5 iv 31; SAA 96 r. 11 (?); SAA 9 7:1; SAA 910 s. 2; SAA 26 10:116; SAA 79 i 23; SAA 10 109:9; SAA 10294 r. 31; SAA 10 352:23; SAA 13 37:7; SAA 13 144 r. 7; MSL 12 6.2:134 see Simo Parpola, Assyrian Prophecies (SAA 9; Helsinki, 1997), pp. XLV-XLVI; Matthijs J. de Jong, Isaiah among the Ancient Near Eastern Prophets: A Comparative Study of the Earliest Stages of the Isaiah Tradition and the Neo-Assyrian Prophecies (VTSup 117; Leiden, 2007), p. 291 292; Jonathan Stökl, Prophecy in the Ancient Near East: A Philological and Sociological Comparison (CHANE 56; Leiden, 2012), pp. 111-127.

${ }^{6}$ SAA 91.1 i $28 ; 1.2$ ii $9 ; 1.3$ ii $13 ; 1.4$ ii $40 ; 1.5$ iii $5 ; 1.7$ v $10 ; 1.8$ v $24 ; 1.10$ vi 31 ; SAA 99 r. 4 (ša pî); SAA 92.3 ii 28; 2.4 iii 18 (issu pî); cf. SAA $26 \S$ 10:116 (ina pî). See Parpola, Assyrian Prophecies, pp. LXIII.

7 Esarhaddon Nin A ii 5-7 (see Erle Leichty, The Royal Inscriptions of Esarhaddon, King of Assyria (680-669 BC) [RINEP 4; Winona Lake, 2011], p. 14); cf. Esarhaddon Ass A ii 12-26 (see ibid., pp. 121, 124); Assurbanipal T ii 14-17 (see Rykle Borger, Beiträge zum Inschriftenwerk Assurbanipals: Die Prismenklassen $A, B, C=K, D, E, F, G$, $H, J$, und T sowie andere Inschriften [Wiesbaden, 1996], p. 140-141, 206).

${ }^{8}$ See Beate Pongratz-Leisten, Herrschaftswissen in Mesopotamien: Formen der Koтmunikation zwischen Gott und König im 2. und 1. Jahrtausend v.Chr. (SAAS 10; Helsinki, 1999), p. 224-226. 
The entire corpus of extant prophetic oracles from Assyria ${ }^{9}$ is the product of the work of professional scribes. ${ }^{10}$ There is nothing in the Neo-Assyrian texts to suggest that the prophets themselves ever wrote down the oracles they spoke, neither is there any particular reason to believe they did so; the complete silence of the sources rather indicates the opposite. There were, for sure, diviners who were intensively involved with writing and text production, as is demonstrated by the abundance of correspondence of the Neo-Assyrian kings with diviners, ${ }^{11}$ but these diviners - haruspices, astrologers, and exorcists - belonged to the class of scholars who were thoroughly versed in traditional omen literature and were expected to write their own reports. Prophets, to all appearances, did not belong to this class, and even though literacy in Mesopotamia may well have been higher than has been expected, ${ }^{12}$ there is nothing to suggest that it was required or expected of prophets. Sometimes their words were recorded in writing by others,,$^{13}$ and there are a few letters reporting prophetic appearances. ${ }^{14}$ In most cases, however, the words they spoke were probably not written down at all.

Similar observations can be made when reading the second major corpus of prophetic documents from the 18th century BCE kingdom of Mari. ${ }^{15}$

9 See the edition in Parpola, Assyrian Prophecies; cf. also Martti Nissinen, Prophets and Prophecy in the Ancient Near East (with contributions by C. L. Seow and Robert K. Ritner; SBLWAW 12; Atlanta, 2003), pp. 101-132.

${ }^{10}$ For scribal characteristics of the Neo-Assyrian prophecies, see Parpola, Assyrian Prophecies, pp. LV-LXII.

${ }^{11}$ See especially Simo Parpola, Letters from Assyrian Scholars to the Kings Esarhaddon and Assurbanipal (AOAT 5/1-2; Kevelaer and Neukirchen-Vluyn, 1970/1983; repr. Winona Lake, 2007); cf. the later editions by Hermann Hunger, Astrological Reports to Assyrian Kings (SAA 8; Helsinki, 1992); Simo Parpola, Letters from Assyrian and Babylonian Scholars (SAA 10; Helsinki, 1993); Steven W. Cole and Peter Machinist, Letters from Priests to the Kings Esarhaddon and Assurbanipal (SAA 13; Helsinki, 1998).

${ }^{12}$ Cf. Dominique Charpin, Reading and Writing in Babylon (trans. Jane Marie Todd; Cambridge, 2010), pp. 53-65.

${ }^{13}$ Cf. especially SAA 13 139; see Martti Nissinen and Simo Parpola, 'Marduk's Return and Reconciliation in a Prophetic Letter from Arbela', in Hannu Juusola, Juha Laulainen, and Heikki Palva (eds.), Verbum et calamus: Semitic and Related Studies in Honour of the Sixtieth Birthday of Professor Tapani Harviainen (StudOr 99; Helsinki, 2004), pp. 199-219; de Jong, Isaiah among the Ancient Near Eastern Prophets, pp. 279-282.

14 E.g., SAA 10 352; 13 37; 13 144; 13 148; 16 59; see Martti Nissinen, References to Prophecy in Neo-Assyrian Sources (SAAS 7; Helsinki, 1998); idem, Prophets and Prophecy in the Ancient Near East, pp. 152-175; and several references to these texts in de Jong, Isaiah among the Ancient Near Eastern Prophets, and Stökl, Prophecy in the Ancient Near East.

${ }^{15}$ For writing, literacy, and the prophetic process of communication at Mari, see Dominique Charpin, 'Le prophétisme dans le Proche-Orient d'après les archives de Mari', in 
Even in these documents, prophecy appears as an oral phenomenon, and the prophetic performance is referred to using verbs denoting speaking or saying, such as qabûm and dabäbum. ${ }^{16}$ There is a profusion of correspondence between the king of Mari and the diviners who, like their Assyrian colleagues a full millennium later, reported their observations and interpretations to the king and who represented a high level of literacy. The prophetic activity at Mari is known to us thanks to some fifty letters reporting, among other things, prophetic words and performances. ${ }^{17}$ These letters typically inform the king about prophets who have 'come' (alākum) or 'risen' (tebûm), sometimes 'gone into frenzy' (mahûm), and 'said' (qabûm/dabābum) divine words that the letter-writers have either experienced themselves or become conversant of by go-betweens. ${ }^{18}$ This implies an ecstatic performance involving oral delivery of divine messages, often in a temple context.

The genre of written prophecies is entirely missing from the Mari archives. There is one tablet, though, that can be seen as representing a type of an oracle collection (ARM 26 194), beginning with the words 'Speak to Zimri-Lim: Thus the prophet of Šamaš'. This is the only letter in the Mari corpus with a prophet as the sender. The letter contains three

Macchi et al (eds.), Les recueils prophétiques de la Bible, pp. 31-73; Jack M. Sasson, 'The Posting of Letters with Divine Messages', in Dominique Charpin and Jean-Marie Durand (eds.), Florilegium Marianum II: Recueil d'études à la mémoire de Maurice Birot (Mémoires de NABU 3; Paris, 1994), pp. 299-316.

${ }^{16}$ FM 7 38:4, 17; 39:29, 36, 42, 46, 61; A 3760:9; ARM 26 197:9, 20; 198:4; 199:29, 43; 200:21; 206:25; 209:7, 17; 210:10; 214:7; 215:16; 220:24; 221:10, 20; 221bis:27; 233:8; 414:30, 34 (qabûm); ARM 26 199:55; 204:5; 206:29; 207: 36-37; 217:27; $219: 6,22 ; 233: 41 ; 243: 8$ (dabäbum). Sometimes the prophetic performance is referred to as 'giving an oracle' (têrtam nadānum): ARM 26:197:5; 200:6; 206:34 (cf. ARM 26 216:8-9; 217:30-31: têrtam epēšum). All three expressions are used in ARM 26206 , suggesting that their meanings virtually overlap. In ARM 26 371: 10, 20, 32, the public proclamation of a prophet of Marduk is described with the Št form of šanû 'proclaim incessantly'.

17 See the editions in Jean-Marie Durand, Archives épistolaires de Mari I/I (ARM 26/1; Paris, 1988); Dominique Charpin, Francis Joannès, Sylvie Lackenbacher, and Bertrand Lafont, Archives épistolaires de Mari I/2 (ARM 26/2; Paris, 1988); Jean-Marie Durand, Florilegium Marianum VII: Le culte d'Addu d'Alep et l'affaire d'Alahtum (Mémoires de NABU 4; Paris, 2002). See also the translations in J.J.M. Roberts, The Bible and the Ancient Near East: Collected Essays (Winona Lake, 2002), pp. 157-253; Wolfgang Heimpel, Letters to the King of Mari: A New Translation, with Historical Introduction, Notes, and Commentary (Mesopotamian Civilizations 12; Winona Lake, 2003); Nissinen, Prophets and Prophecy in the Ancient Near East, pp. 13-77.

18 E.g., FM 7 38:4; 7 39:47; ARM 26 197:8; 199:43; 206:6; 210:8; 212:6; 220:10; 221bis:13; 223:5; 414:30; ARM 27 32:9 (aläkum); A. 3760:6; ARM 26 195:7; $204: 5 ; 209: 7,16 ; 215: 16 ; 219: 5 ; 237: 23$ (tebûm); ARM 26 213:7; 214:7; 222:6, 13 (mahûm); for qabûm/dabābum, see above, fn. 15 . 
or four individual prophecies of Šamaš and ends with the exhortation: 'Let Zimri-Lim, governor of Šamaš and Adad, listen to what is written on this tablet...'. The tablet, hence, could be characterized as a collection of oracles embedded in a letter.

What exactly is the role of the prophet as the sender of this letter? Could he have written it himself? That this is not the case becomes evident from another letter (ARM 26 414), in which the official Yasim-El reports the king the following:

'Another matter: Atamrum, prophet of Šamaš, came to me and spoke to me as follows: "Send me a discreet scribe! I will have him write down the message which Šamaš has sent me for the king." This is what he said to me. So I sent Utu-kam and he wrote this tablet. This man brought witnesses and said to me as follows: "Send this tablet quickly and let the king act according to its words." This is what he said to me. I have herewith sent this tablet to my lord.'

Dominique Charpin has argued convincingly that the letter sent 'herewith' to the king is nothing else but the above-mentioned letter ARM 26194 containing the message of Šamaš. ${ }^{19}$ If this is true, these two letters, one accompanying the other, give us a rare description of how written prophecies came into being. The prophet Atamrum, apparently, could not write himself, so Yasim-El commissioned a professional scribe called Utu-kam to write down the divine message which was then forwarded to the king by Yasim-El, together with another letter containing other reports. This is the only text from Mari connecting a prophet with any kind of writing, and it shows that, even though the prophet himself does not seem to have had scribal skills, he knew how to use written media in transmitting the divine word to its addressee.

Apart from the two main corpora of documentation of prophecy, there are two of texts that associate prophets with writing, both coming from places close to the biblical landscape. The famous prophetic text from Tell Deir 'Alla ${ }^{20}$ begins with the words: 'The warning of the book (spr)

${ }_{19}$ Dominique Charpin, 'Prophètes et rois dans le Proche-Orient amorrite: Nouvelles données, nouvelles perspectives', in Dominique Charpin and Jean-Marie Durand (eds.), Florilegium Marianum VI: Récueils d'études à la mémoire d'André Parrot (Mémoires de NABU 7; Paris, 2002), pp. 7-38, esp. 14-15; cf. idem, 'Le prophétisme dans le Proche-Orient d'après les archives de Mari', p. 36.

${ }^{20}$ Editio princeps: Jacob Hoftijzer and Gerrit van der Kooij, Aramaic Texts from Deir 'Alla (DMOA 19; Leiden, 1976); for later editions, see, e.g., Helga Weippert and Manfred Weippert, 'Die "Bileam”-Inschrift von Tell Dēr 'Allä', ZDPV 98 (1982), pp. 77-103 (= Manfred Weippert, Jahwe und die anderen Götter: Studien zur Religionsgeschichte des antiken Israel im syrisch-palästinischem Kontext [FAT 18; Tübingen, 
of [Balaam, son of Beo]r, ${ }^{21}$ who was a seer of the gods'. The text, written in a language akin to Aramaic and Hebrew is dated to the 8th century. It was originally written on the plaster of the wall of a small building. Interestingly, this 'writing on a wall' is called a 'book' - that is, a scroll which indicates that the text had been copied on the plaster from another source, perhaps even compiled of originally independent texts. The Deir 'Alla text, hence, provides compelling evidence of writing and editing prophetic texts just a little before we see the the first biblical 'writing' prophets appearing on the other side of the river Jordan. ${ }^{22}$ The text does not, however, say anything about who actually and originally wrote it; the title 'Book of Balaam' names Balaam as the central character of the text, not as its author or writer.

Finally, an extrabiblical text from the kingdom of Judah should be quoted here, that is, the Lachish Ostracon no. 3. The letter is sent by Hoshaiah to Yaush, the military commander at Lachish, some time before the collapse of Jerusalem in 586 BCE, and it ends with the following lines: 'As for the letter of Tobiah the servant of the king, which came to Shallum the son of Jaddua from the prophet, saying: "Beware!" - your servant has sent it to my lord'. ${ }^{23}$ The letter refers to a process of communication that involves five different persons and is difficult to reconstruct. Who is to be imagined as the actual writer of the 'letter of Tobiah' (ספר טביהו) that 'came to Shallum' (הבא אל שלם) 'from the prophet' (מאת הנבא), which 'your servant' (that is, Hoshaiah) has sent to his 'lord' (that is, Yaush)? Perhaps the royal official Tobiah had become aware of

1997], pp. 131-161); Jo Ann Hackett, The Balaam Text from Deir 'Allā (HSM 31; Chico, 1984); Choon-Leong Seow in Nissinen, Prophets and Prophecy in the Ancient Near East, pp. 207-212; Erhard Blum, 'Die Kombination I der Wandinschrift von Tell Deir 'Alla: Vorschläge zur Rekonstruktion mit historisch-kritischen Anmerkungen', in Ingo Kottsieper, Rüdiger Schmitt, and Jakob Wöhrle (eds.), Berührungspunkte: Studien zu Sozial- und Religionsgeschichte Israels und seiner Umwelt, Festschrift für Rainer Albertz zu seinem 65. Geburtstag (AOAT 350; Münster, 2008), pp. 573-601.

21 The name is fully preserved on line 4.

22 Cf. Erhard Blum, 'Israels Prophetie im altorientalischen Kontext: Anmerkungen zu neueren religionsgeschichtlichen Thesen', in Izak Cornelius and Louis Jonker (eds.), 'From Ebla to Stellenbosch': Syro-Palestinian Religions and the Hebrew Bible (ADPV 37; Wiesbaden, 2008), pp. 81-115; Émile Puech, 'Bala'am and Deir 'Alla', in George H. van Kooten and Jacques T.A.G.M. van Ruiten (eds.), The Prestige of the Pagan Prophet Balaam in Judaism, Early Christianity, and Islam (TBN 11; Leiden, 2008), pp. $25-47$.

23 Lak (6):1.3 r. 3-5; edition: Johannes Renz, Die althebräischen Inschriften, Teil 1: Text und Kommentar (Handbuch der althebräischen Epigraphik 1; Darmstadt, 1995), pp. 412-419; cf. Choon-Leong Seow in Nissinen, Prophets and Prophecy in the Ancient Near East, pp. 212-215. 
the 'Beware!' prophecy and written a report of it that had then been mediated to Hoshaiah, the present letter-writer, by Shallum. ${ }^{24}$ In any case, the letter tells about another letter, the essential contents of which comprises a prophetic oracle. The letter may have been sent on the prophet's initiative. It does not indicate that the prophet (the only anonymous member in this chain of communication ${ }^{25}$ ) had written the prophecy down himself, but it may reflect a process of communication similar to that in the case of the prophecy of Atamrum described above (ARM 26414 ).

The survey of available evidence leaves empty-handed anyone who wants to find writing prophets in the ancient Near East: not a single source from the entire Near Eastern documentation even remotely alludes to a prophet writing a text her- or himself. The best explanation of the complete silence of the sources is that prophets simply did not belong to the class of literati at Mari or in Assyria, or anywhere in the ancient Near East. On the other hand, there is firm evidence of the connection between the prophetic and scribal practices: prophecies were occasionally, even though not routinely, written down, and, as the letter ARM 26414 from Mari and the Lachish Ostracon 3 demonstrate, the prophets may sometimes have even initiated the scribal process.

\section{HeBRew Bible}

As Michael Floyd fittingly notes, '[t]he Bible's narrative descriptions of prophets hardly ever involve written documents' ${ }^{26}$ To be sure, persons designated as prophets are sometimes depicted as writing a text themselves in the Hebrew Bible, but this does not happen very often - only

${ }^{24}$ Udo Rüterswörden, 'Der Prophet der Lachish-Ostraka', in Christof Hardmeier (ed.), Steine-Bilder-Texte: Historische Evidenz außerbiblischer und biblischer Quellen (Arbeiten zur Bible und ihrer Geschichte 5; Leipzig, 2001), pp. 179-192, esp. 187: 'Die einleuchtendste Erklärung besteht darin, dass der ספס von Ṭōbyāhû stammt, der wesentliche Inhalt aber - vor allem mit dem Kurzzitat - von dem Propheten'. Cf. also Simon B. Parker, 'The Lachish Letters and Official Reactions to Prophecies', in Lewis M. Hopfe (ed.), Uncovering Ancient Stones: Essays in Memory of H. Neil Richardson (Winona Lake, 1994), pp. 65-78.

25 According to an alternative interpretation, Tobiah himself is the prophet; thus Stökl, Prophecy in the Ancient Near East, p. 170. The definitive article in הנבא points to this direction, but the title 'servant of the king' sounds somewhat strange as a prophetic title.

${ }^{26}$ Michael H. Floyd, “'Write the Revelation!” (Hab 2:2): Re-imagining the Cultural History of Prophecy', in Ehud Ben Zvi and Michael H. Floyd (eds.), Writings and Speech in Israelite and Ancient Near Eastern Prophecy (SBLSymS 10; Atlanta, 2000), pp. 103-143, esp. 103. 
five times, to be precise. In 1 Sam 10:25, Samuel, having told the people the rights and duties of the kingship of the newly elected king Saul, 'wrote them in a book (יכתב בספר) and laid it up before the Lord'. ${ }^{27}$ In Jer 32:10-12, Jeremiah buys a field at Anatoth from his cousin and says:

'I signed the deed (lit. "wrote in a book", ואכתב בספר), sealed it, got witnesses, and weighed the money on scales. Then I took the sealed deed of purchase, containing the terms and conditions, and the open copy; and I gave the deed of purchase to Baruch son of Neriah son of Mahseiah, in the presence of my cousin Hanamel, in the presence of the witnesses who signed the deed of purchase (הכתבים הספר המקנה), and in the presence of all the Judeans who were sitting in the court of the guard'.

Jeremiah is also said to have written down his oracles against Babylon: 'Jeremiah wrote in a scroll (ספר ויכתב ירמחהו ... אל אל all the disasters that would come on Babylon, all these words that are written concerning Babylon'." (Jer 51:60). In Chronicler's report of the reign of Uzziah it reads: 'Now the rest of the acts of Uzziah (ויתר דברי עזיהו), from first to last, the prophet Isaiah son of Amoz wrote (2) ' כ כתב Chr 26:22). Finally, Daniel (as far can he can be called a prophet ${ }^{28}$ ) is once said to have written down (בתכ) his own dream (Dan 7:1).

Moreover, two prophets are presented as sending a letter without indicating who is thought to have actually written them. Jeremiah 29 includes a letter 'that the prophet Jeremiah sent (שלח) from Jerusalem to the remaining elders among the exiles, and to the priests, the prophets, and all the people'; and in 2 Chr 21:12-15, king Jehoram of Judah becomes a letter from the prophet Elijah (מעליהו הנביא מכתב). In both cases, the contents of the letter consists of words of Yahweh, hence the letters can also be regarded as oracular accounts.

The documents that are said to have been written by a prophet include two legal documents, two oracular reports, one historical account, and, perhaps, two letters. All these text types are well known from the Near East, but apart from the Bible, we never find a prophet writing such texts. Even the biblical cases are not very conclusive: Samuel is not really acting as

27 The translations of the Hebrew Bible follow the NRSV.

28 Daniel is called a prophet in the Dead Sea Scrolls (4QFlor frag. 1, II, 3, 24, 5:3) and the New Testament (Matt. 24:15), but not in the Hebrew Bible; however, his image has much in common with biblical prophets, such as Amos and Jeremiah; cf. Lester L. Grabbe, 'Daniel: Sage, Seer ... and Prophet?', in Lester L. Grabbe and Martti Nissinen (eds.), Constructs of Prophecy in the Former and Latter Prophets and Other Texts (ANEM 4; Atlanta, 2011), pp. 87-94. 
a prophet when writing the king's rights, ${ }^{29}$ and Jeremiah's 'writing' (כתב) of the purchase document refers to his signature rather than to writing the whole document - the same verb is used of the witnesses. Daniel, on the other hand, is depicted as belonging to the scribal elite (Dan 1:3-7).

In addition to the texts referring explicitly to a prophet performing the act of writing, in a number of texts a prophet receives the divine command to write; all of them use the verb כתב:

Isa 8:1-2: 'Then the Lord said to me, Take a large tablet and write on it in common characters, "Belonging to Maher-shalal-hash-baz," and have it attested for me by reliable witnesses, the priest Uriah and Zechariah son of Jeberechiah'.

Isa 30:8: 'Go now, write it before them (אתם) on a tablet (לוח), and inscribe it in a book (ספר), so that it may be for the time to come as a witness forever'.

Ezek 24:1-2: 'In the ninth year, in the tenth month, on the tenth day of the month, the word of the Lord came to me: Mortal, write down the name of this day, this very day. The king of Babylon has laid siege to Jerusalem this very day'.

Ezek 37:15-16: 'The word of the Lord came to me: Mortal, take a stick (עץ אחד) and write on it, "For Judah, and the Israelites associated with it"; then take another stick and write on it, "For Joseph (the stick of Ephraim) and all the house of Israel associated with it"'.

Hab 2:2: 'Then the Lord answered me and said: Write the vision; make it plain on tablets (לחות), so that a runner may read it. For there is still a vision for the appointed time; it speaks of the end, and does not lie'.

Jer 30:2: 'Thus says the Lord, the God of Israel: Write in a book (ספר) all the words that I have spoken to you'.

Jer 36:1-2: 'In the fourth year of King Jehoiakim son of Josiah of Judah, this word came to Jeremiah from the Lord: Take a scroll (מגלת ספר) and write on it all the words that I have spoken to you against Israel and Judah and all the nations, from the day I spoke to you, from the days of Josiah until today'.

Jer 36:27-28: 'Now, after the king had burned the scroll with the words that Baruch wrote at Jeremiah's dictation, the word of the Lord came to Jeremiah: Take another scroll (מגלה) and write on it all the former words that were in the first scroll (...)'.

${ }^{29}$ Walter Dietrich, 'Samuel - ein Prophet?', in Joseph Verheyden, Korinna Zamfir, and Tobias Nicklas (eds.), Prophets and Prophecy in Jewish and Early Christian Literature (WUNT 2/286; Tübingen, 2010), pp. 1-17, esp. 9: 'Hier agiert Samuel wieder nicht als Prophet, sondern als Leiter eines Volks-Things, vielleicht auch als Priester, der ein kultisches Los- und Orakelverfahren leitet'. 
Some of these divine commands imply short inscriptions carved on stone (Isa 8:1) or a piece of wood (Ezek 37:16). In these cases, the act of writing, together with the text itself, fulfills a primarily symbolic and magical function rather than that of a prophetic oracle. ${ }^{30}$ These texts seem to presuppose that the prophets in question were able to produce texts comprising a few words, and hence 'possessing at least basic literacy', ${ }^{31}$ but they do not present prophets as producing written prophecies, or even otherwise participating in their creation.

More to the point are the texts to be inscribed on the tablet and the scroll in Isa 30:8, and on the tablets in Hab 2:2. These texts read like short oracles written down, publicized,,$^{32}$ and preserved as a testimony for the coming generations. They do not even imply an oral proclamation of the words to be written down; what matters much more is their applicability for reinterpretation by the posterity. ${ }^{33}$ The same function is evident in

${ }^{30}$ Cf. Reinhard G. Kratz, " "Siehe ich lege meine Worte in deinen Mund”: Die Propheten des Alten Testaments', in Reinhard Feldmeier and Hermann Spieckermann (eds.), Die Bibel: Entstehung-Botschaft_Wirkung (Göttingen, 2004), 24-39 = idem, Prophetenstudien, 18-31, quoted from p. 24: 'Es handelt sich um eine Symbolhandlung, die Öffentlichkeit herstellt und zugleich magische Bedeutung hat'.

31 David M. Carr, Writing on the Tablet of the Heart: Origins of Scripture and Literature (New York, 2005), p. 118.

32 The expression 'before them' (Isa 30:8) and the reference to the 'runner' in Hab 2:2 (actually: 'town-crier'; see Joachim Schaper, 'On Writing and Reciting in Jeremiah 36', in Hans M. Barstad and Reinhard G. Kratz [eds.], Prophecy in the Book of Jeremiah [BZAW 388; Berlin, 2009], pp. 137-147, esp. 143-144) indicate that the texts are meant to be seen or heard by an audience.

33 See Michael H. Floyd, 'Prophecy and Writing in Habakkuk 2,1-5', ZAW 105 (1993), pp. 462-481, esp. 477; Wolfgang Zwickel, 'Kommunikation und Kommunikationsmöglichkeiten im alten Israel aufgrund biblischer und außerbiblischer Texte', in Andreas Wagner (ed.), Bote und Brief: Sprachliche Systeme der Informationsübermittlung im Spannungsfeld von Mündlichkeit und Schriftlichkeit (Nordostafrikanisch/westasiatische Studien 4; Frankfurt am Main, 2003), pp. 113-123, esp. 116: 'In Jes 30,8; Jer 30,2 (dtr.); Hab 2,2 geht es nicht um eine Niederschrift prophetischen Überlieferung im herkömmlichen Sinne, sondern um ein bewußtes Festhalten als Zeugnis für die Nachwelt. Prophetische Botschaft soll hier um ihrer Überprüfbarkeit willen schriftlich festgehalten werden, nicht um der Wertigkeit als theologischer Text willen. Hinter diesen Texten steht somit schon das dtr. Prophetengesetz Dtn 18,21f.'. Cf. de Jong, Isaiah among the Near Eastern Prophets (p. 113): ' $30: 8$, originally the conclusion of 30:6-8, became a fundamental statement of the necessity of written documentation of the rejected prophetic words, as a part of a literary reworking of the earlier prophetic material [scil. in 30:911]'. According to Reinhard G. Kratz, 'Rewriting Isaiah: The Case of Isaiah 28-31', in John Day (ed.), Prophecy and the Prophets in Ancient Israel: Proceedings of the Oxford Old Testament Seminar (LHBOTS 531; New York-London, 2010), pp. 245266 (= 'Jesaja 28-31 als Fortschreibung', in idem, Prophetenstudien, pp. 177-197), the command to write in $30: 8$ corresponds to $8: 16$ as a part of the Fortschreibung of Isaiah 1-12 in Isaiah 28-31. 
Isa 8:16: 'Bind up the testimony (תעודה), seal the teaching (תורה) among my disciples'; this is usually interpreted as referring to a small collection of oracles (such as the so-called Denkschrift of Isaiah). ${ }^{34}$ These three verses have often been interpreted as direct evidence of the prophets Isaiah and Habakkuk taking care of the written documentation of their words. It is important to note, however, that the divine commands to write form part of the literary structure of the oracles themselves, hence it is very difficult to know whether they can be read as reports of something that was actually done. ${ }^{35}$ At best, they can be read as reflecting a common imagination of what could have taken place in the writers' or readers' real world.

The production of all these texts is presented as imitating a legal procedure: the text is written, read aloud, and notarized in the presence of witnesses and preserved as a binding document and a testimony for the posterity: "As a sealed real estate transaction serves to guarantee proof of title (e.g., Jer 32:9-15), so the written text committed to the prophet's disciples and protected by its seal guarantees the authenticity of the prophecy'. ${ }^{36}$ Writing, hence, is understood here in the same way as in Jer 32:10 as a part of the legal act, and the text equals to a legally binding document also in that what is written is simultaneously enforced. The

34 E.g., de Jong, Isaiah among the Near Eastern Prophets (p. 80): 'The testimony and

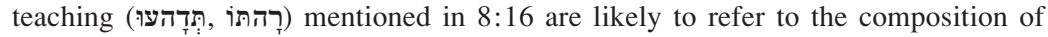
Isa 6-8 itself'. The 'testimony and teaching' here is clearly distinct form the text mentioned in $8: 1$, and it is not indicated who is thought to have actually written the text referred to here. More emphasis is (rightly) given to Isaiah's followers, whether the so-called 'disciples' (thus, among many others, Carr, Writing on the Tablet of the Heart, pp. 143-145) or the scribes who took care of the formation of the early forms of the book of Isaiah (cf. Martti Nissinen, 'Das Problem der Prophetenschüler', in Juha Pakkala and Martti Nissinen [eds.], Houses Full of All Good Things: Essays in Memory of Timo Veijola [Publications of the Finnish Exegetical Society 95; Helsinki, 2008], pp. 337353, esp. 349-351).

35 This is presupposed by Floyd, 'Prophecy and Writing in Habakkuk 2,1-5', p. 471 who reads Hab 2:1-5 as 'the report of an oracular inquiry', that 'reflects a complex underlying course of events'. It is possible, however, that neither Hab 2:1-5 nor Isa 8:16 and 30:8 are transcriptions of an actual order received by the prophets, but, rather, literary imaginations based on a common practice of textual production; thus de Jong, Isaiah among the Near Eastern Prophets, p. 56, and Joseph Blenkinsopp, Isaiah 1-39: A New Translation with Introduction and Commentary (AB 19; New York, 2000), p. 415.

36 Joseph Blenkinsopp, Opening the Sealed Book: Interpretations of the Book of Isaiah in Late Antiquity (Grand Rapids, 2006), 13. See also Schaper, 'On Reading and Reciting Jeremiah 36', 145; Kevin Cathcart, "'Law is Paralysed” (Habakkuk 1.4): Habakkuk's Dialogue with God and the Language of Legal Disputation', in Day (ed.), Prophecy and the Prophets in Ancient Israel, pp. 339-353. 
identity of the scribe is ancillary to that of the commissioner of the document. In the case of prophetic words, the prophet acts on behalf of the actual divine commissioner of the deed, whether or not he is thought to write it him/herself. The focus is clearly (1) on the written product itself as containing testimony of divine words that transcend the particular moment when they are first uttered (or written); and (2) on the later generations for whom this testimony is meant.

Seen from this perspective, the divine command to write does not need to be understood as literally as the translations suggest, let alone as implying the literacy of the prophets. In fact, the verb כתב seems to refer to the whole process of production and authorization of the text, not merely to the physical act of writing. ${ }^{37}$ This can be illustrated by the case of Jeremiah's scroll related in Jeremiah $36 .{ }^{38}$ God ordered the prophet Jeremiah to take a scroll and write the divine words on it, so 'Jeremiah called Baruch son of Neriah, and Baruch wrote on a scroll at Jeremiah's dictation (מפי ירמיהו) all the words of the Lord that he had spoken to him' (Jer 36:4; cf. 45:1). All this looks a lot like what happened at Mari between Atamrum the prophet of Šamaš, Utu-kam the scribe, Yasim-El the official, and King Zimri-Lim (ARM 26 414). ${ }^{39}$ Divine words are mediated

${ }^{37}$ It deserves attention that the verb is never used in Hiph'il in biblical Hebrew, as if there was no need for a causative meaning of the verb. Even in the Dead Sea Scrolls, the Hiph'il form of the verb is attested only once in 4 QJub ${ }^{\text {a }} 1: 27$ (see $D C H 4: 474$ ).

38 The recent profusion of literature on Jeremiah 36, highlighting the chapter as documenting and/or reflecting the emergence of prophetic literature from various angles, includes, e.g., Joëlle Ferry, “Le livre dans le livre”: Lecture de Jérémie 36', in Macchi et al. (eds.), Les recueils prophétiques de la Bible, pp. 283-306; Schaper, 'On Writing and Reciting Jeremiah 36'; Mark Leuchter, The Polemics of Exile in Jeremiah 26-45 (New York, 2008), pp. 82-112; Christof Hardmeier, 'Zur schriftgestützten Expertentätigkeit Jeremias im Milieu der Jerusalemer Führungseliten (Jeremia 36): Prophetische Literaturbildung und die Neuinterpretation älterer Expertisen in Jeremia 21-23', in Joachim Schaper (ed.), Die Textualisierung der Religion (FAT 62; Tübingen, 2009), pp. 105149; idem, 'Schriftgebrauch und Literaturbildung im Milieu der Jerusalemer Führungseliten in spätvorexilischer Zeit (Jeremia 36)', in Kottsieper, Schmitt, and Wöhrle (eds.), Berührungspunkte, pp. 267-290; Van der Toorn, Scribal Culture and the Making of the Hebrew Bible, pp. 184-188; Hermann-Josef Stipp, 'Baruchs Erben: Die Schriftprophetie im Spiegel von Jer 36', in Hubert Irsigler (ed.), 'Wer darf hinaufsteigen zum Berg JHWHs?': Beiträge zu Prophetie und Poesie des Alten Testaments, Festschrift für Sigurður Örn Steingrímsson zum 70. Geburtstag (ATSAT 72; St. Ottilien, 2002), pp. 145-170; Harald Martin Wahl, 'Die Entstehung der Schriftprophetie nach Jer 36', ZAW 110 (1998), pp. 365-389.

${ }^{39}$ Cf. Schaper, 'On Writing and Reciting Jeremiah 36', pp. 141-142, referring to Abraham Malamat, 'New Light from Mari (ARM XXVI) on Biblical Prophecy', in Daniele Garrone and Felice Israel (eds.), Storia e tradizioni di Israele: Scritti in onore di J. Alberto Soggin (Brescia, 1991), 185-190 (= idem, Mari and the Bible [SHCANE 12; Leiden, 1998], pp. 128-133). 
by a prophet who commissions a professional scribe; the scribe writes the tablet and takes care of its transportation to the king, but the prophet still appears as its actual author on behalf of the god Šamaš. In both cases, the addressee of the divine message cannot be reached by means of oral communication, hence the prophetic process of communication requires the use of written media as a surrogate for the oral proclamation.

The very act of writing, let alone the individual who is imagined to have physically performed it, is clearly subordinate to the divine actor who is believed to be the actual subject of the message. Still, the person of the prophet is not without significance as the human mediator of the divine word. The Near Eastern texts usually mention the name of the prophet, because there is no divination without the diviner. In the divinatory - or prophetic - process of communication, the identity of the divinely commissioned human mediator must be known in order to be able to become convinced of that the message comes from a reliable source and, in the case of need, to test the trustworthiness of the prophet. ${ }^{40}$ The prophets are sometimes bestowed with an individual agency, ${ }^{41}$ and a prophet can even be credited with a certain kind of authorship, as in the cases of the prophets Atamrum and Jeremiah.

The scroll of Jeremiah, however, differs from the case of Atamrum in one significant respect. When this scroll had been destroyed by Jehoiakim, God told Jeremiah to take another scroll and write on it. Again, it was Baruch who rewrote the contents of the first scroll: 'And many similar words were added (Niph'al: נוסף) to them' (Jer 36:32). This signals something that is unheard of elsewhere in ancient Near Eastern sources. Even though Atamrum's letter can be read as a small collection of oracles of Šamaš, and the practice of compiling collections of prophecies is wellknown from Assyria, this is the first time we hear of divine words attributed to one and single prophet on a scroll, reedited and supplemented by new material by anonymous scribes.

Evidently, we are witnessing a new development in the history of Near Eastern prophecy: the birth of a prophetic book. Depending on how we perceive the textual growth in Jeremiah 36 , it is possible that

${ }^{40}$ For example, by enclosing the prophet's 'hair and fringe' (šärtum u sissiktum) in letters reporting the prophets' performances at Mari; see recently Esther J. Hamori, 'Gender and the Verification of Prophecy at Mari', WO 42 (2012), pp. 1-22.

${ }^{41}$ For prophetic agency, see my article 'Gender and Prophetic Agency in the Ancient Near East', forthcoming in Jonathan Stökl and Corrine L. Carvalho (eds.), Prophets Male and Female: Gender and Prophecy in the Hebrew Bible, the Eastern Mediterranean and the Ancient Near East (Ancient Israel and Its Literature; Atlanta). 
in earlier versions of the story ${ }^{42}$ the scope was narrower, focusing on the public reading of the scroll as a substitute to oral delivery rather than to its scribal Überlieferung. In its more advanced form available to us, however, Jeremiah 36 presents itself outspokenly as a scribal work, highlighting the agency of Baruch the scribe. ${ }^{43}$ Even the whole book of Jeremiah, as we know it, refers to itself in 30:2, in 45:1, and especially in 25:13:

'I will bring upon that land all the words that I have uttered against it, את כל) של (הת) הכתוב בספר הזה אשר נבא ירמיהו against all the nations'.

It is noteworthy that the verb כתב is here in passive: the activity of the prophet is not described as writing but as prophesying. Nonetheless, the person of the prophet is not indifferent; on the contrary, it authenticates the prophetic process of communication in which the agency of the prophet is duly acknowledged. Compared to the traditional patterns of prophetic communication, however, the very writtenness of the divine word becomes an unprecedented emphasis. The scroll becomes a medium that not only fulfills the function of keeping records for posterity but also exists as a reference work on its own right, becoming a medium of the divine revelation itself. ${ }^{44}$

Traditionally in the ancient Near East, the written version of a prophetic oracle was understood as a transcript of the original message that existed independently from the written tablet. In Jeremiah, the written product is clearly on its way of claiming the authority of the divine word for itself as the final and definitive account of the divine word. This development goes even further in the book of Ezekiel where the written document is the prerequisite for oral prophecy, not vice versa. This is powerfully illustrated in Ezek 2:9-3:3 where a written scroll is opened in front of the prophet who opens his mouth and God gives him a scroll to eat: 'He said to me, Mortal, eat this scroll that I give you and fill your stomach with it.

42 The earliest layer of Jer 36 has been identified in vv. 1-2b, 4-6, 8, 10-30 by Wahl, 'Die Entstehung der Schriftprophetie nach Jer 36', p. 372; in vv. 5-6a, 8a, 14-16, 20-27aba; 28-30 by Stipp, 'Baruchs Erben', pp. 157-160; and in vv. 1, 4-5a, 8-14aa; 14b, 15b-16aba; 20-26 by Hardmeier, 'Zur schriftgestützten Expertentätigkeit Jeremias', pp. 142-145.

43 So recently Ferry, "Le livre dans le livre": Lecture de Jérémie 36', pp. 300-303; Leuchter, The Polemics of Exile in Jeremiah 26-45, pp. 101-102.

${ }^{44}$ Cf. Hindy Najman, 'The Symbolic Significance of Writing in Ancient Judaism', in Hindy Najman and Judith H. Hewman (eds.), The Idea of Biblical Interpretation: Essays in Honor of James L. Kugel (JSJSup 83; Leiden, 2004), pp. 139-173, esp. 169; Jonathan Ben-Dov, 'Writing as Oracle and as Law: New Contexts for the Book-Find of King Josiah', JBL 127 (2008), pp. 223-239, esp. 236-236. 
Then I ate it; and in my mouth it was as sweet as honey' (3:3). Here the prophetic process of communication changes at a crucial point; in the words of Joachim Schaper, 'God himself is depicted as an author/scribe and as requiring humans to make use of writing in order to further the effectiveness of his own oracles'. ${ }^{45}$ The prophet and priest Ezekiel may well have been a literate person, but the book of Ezekiel is not interested in his literacy; instead, it presents him as a visionary and proclaimer of a text, in the production of which he himself does not participate. Ezekiel is commissioned by God to speak (3:4), not to write, except for the two above-mentioned cases $(24: 2 ; 37: 16)$ where the short inscriptions belong to symbolic-magical actions accompanied by an oral sermon.

Whereas the role of the prophet in the textual production is recognized in the books of Isaiah and Habakkuk and emphasized in the book of Jeremiah, in the book of Ezekiel it fades away in favor of an idealized conception of a divinely authored text that appears in a written form in the first beginning and serves as the basis of the oral prophetic proclamation.

The prophets Jeremiah and Ezekiel are positioned differently with regard to the written texts; however, both are related to, even though not quite identical with, the Deuteronom(ist)ic concept of the book of Torah (ספר התורה) and the role of Moses as the prophet who proclaims it. In Deut 31:26-28, the book of Torah appears as a written document, placed next to the ark of the covenant and remaining there as a witness for coming generations:

'Take this book of the law (ספר התורה) and put it beside the ark of the covenant of the Lord your God; let it remain there as a witness against you. For I know well how rebellious and stubborn you are. If you already have been so rebellious toward the Lord while I am still alive among you, how much more after my death! Assemble to me all the elders of your tribes and your officials, so that I may recite these words in their hearing and call heaven and earth to witness against them'.

As a witness for the posterity, the book of Torah is reminiscent of the prophecies mentioned in Isa 30:8 and Hab 2:2.46 More than these individual prophecies, however, the written text of the Torah is presented a transtemporal focal point of the whole community "created by the shared

45 Joachim Schaper, 'Exilic and Post-Exilic Prophecy and the Orality/Literacy Problem', VT 55 (2005), pp. 324-342, esp. 333. Cf. Ellen F. Davis, Swallowing the Scroll: Textuality and the Dynamics of Discourse in Ezekiel's Prophecy (JSOTSup 78; Sheffield, 1989).

${ }^{46}$ Cf. Carr, Writing on the Tablet of the Heart, p. 145. 
reading of shared texts and the shared imagination of lasting "realities" that resulted from this reading, ${ }^{47}$ In the Deuteronom(ist)ic imagination, Moses is the model of every true prophet (Deut 18:15-18), and Ezekiel compares to him first and foremost as the proclaimer of a text written by God himself (Exod 32:16; 34:1). According to this ideology, the prophet is a mere proclaimer of Torah without any independent agency or authorship. In the case of Jeremiah, again, the link between Moses and Jeremiah manifests itself in the similar agency of both prophets, even including a role in textual production (cf. Exod 34:27). ${ }^{48}$ Both in Ezekiel and in Jeremiah, the text remains the actual site of the divine revelation.

Yet a different idea of the association between prophecy and writing is provided by Chronicles, where the prophets assume an important role as inspired messengers. ${ }^{49}$ Chronicles report a significant number of prophetic appearances, most of which are unique to Chronicles and not derived from Samuel-Kings. Many of the Chronicler's prophets are interpreters of historical events involved in text production, notably Elijah who in Chronicles does not perform miracles but sends a letter to King Jehoram (2 Chr 21:12-15), and Jeremiah who 'uttered a lament for Josiah' that is said to have been 'written in the lamentation' (כתובים על הקינות; $2 \mathrm{Chr} 35: 25)$. It is not indicated whether Elijah and Jeremiah are thought of as having written these texts themselves, but at least in the case of Jeremiah, a reference is made to an existing collection of texts, among which his lamentation can be found.

${ }^{47}$ Ehud Ben Zvi, 'Imagining Josiah's Book and the Implications of Imagining It in Early Persian Period', in Kottsieper, Schmitt, and Wöhrle (eds.), Berührungspunkte, pp. 193212, esp. 201

48 See Christopher R. Seitz, 'The Prophet Moses and the Canonical Shape of Jeremiah', ZAW 101 (1989), pp. 3-27; cf. Ferry, 'Le livre dans le livre', pp. 296-299.

${ }^{49}$ Prophets and prophecy in Chronicles has been studied intensively in during the recent years; see, e.g., Pancratius C. Beentjes, 'Constructs of Prophets and Prophecy in the Book of Chronicles', in Grabbe and Nissinen (eds.), Constructs of Prophecy in the Former and Latter Prophets and Other Texts, pp. 21-40; Louis Jonker, 'The Chronicler and the Prophets: Who Were His Authoritative Sources?', in Ehud Ben Zvi and Diana Edelman (eds.), What Was Authoritative for Chronicles? (Winona Lake, 2011), pp. 145164; Amber K. Warhurst, 'The Chronicler's Use of the Prophets', ibid., pp. 165-181; Gary N. Knoppers, 'Democratizing Revelation? Prophets, Seers and Visionaries in Chronicles', in Day (ed.), Prophecy and the Prophets in Ancient Israel, pp. 391-409; Yairah Amit, 'The Role of Prophets and Prophecy in the Chronicler's World', in Floyd and Haak (eds.), Prophets, Prophecy and Prophetic Texts in the Second Temple Period, pp. 80-101; William M. Schniedewind, The Word of God in Transition: From Prophet to Exegete in the Second Temple Period (JSOTSup 197; Sheffield, 1995); Jürgen Kegler, 'Prophetengestalten im Deuteronomistischen Geschichtswerk und in den Chronikbüchern: Ein Beitrag zur Kompositions- und Redaktionsgeschichte der Chronikbüchern', ZAW 105 (1993), pp. 481-497. 
The Book of Chronicles is written in a world where texts have become important, if not principal, sources of revelation. This is made plain, not only by direct citations and unacknowledged allusions, but also by frequent source references. ${ }^{50}$ Many of the Chronicles' source references refer to works of prophets or seers; in most cases, in fact, prophets appear as annalists and record-keepers of the kings of Judah. ${ }^{51}$ The most explicit reference is 2 Chr 26:22:

'Now the rest of the acts of Uzziah, from first to last, the prophet Isaiah son of Amoz wrote'.

There are six further references to the deeds of the kings written in the records of prophets:

1 Chr 29:29: 'Now the acts of King David, from first to last, are written (כתובים) in the records of (על דברים) the seer Samuel, and in the records of the prophet Nathan, and in the records of the seer Gad'.

2 Chr 9:29: "Now the rest of the acts of Solomon, from first to last, are they not written in the history of the prophet Nathan, and in the prophecy (נבואה) of Ahijah the Shilonite, and in the visions (חזות) of the seer Iddo concerning Jeroboam son of Nebat?'

2 Chr 12:15: 'Now the acts of Rehoboam, from first to last, are they not written in the records of the prophet Shemaiah and of the seer Iddo, recorded by genealogy?'

2 Chr 13:22: 'The rest of the acts of Abijah, his behavior and his deeds, are written in the story (מדרש) of the prophet Iddo.'

2 Chr 32:32: 'Now the rest of the acts of Hezekiah, and his good deeds, are written in the vision of the prophet Isaiah son of Amoz in the Book of the Kings of Judah and Israel'.

2 Chr 33:19: 'His [Manasseh's] prayer, and how God received his entreaty, all his sin and his faithlessness, the sites on which he built high places and set up the sacred poles and the images, before he humbled himself, these are written in the records of the seers'.

Some of these prophets are familiar from Samuel-Kings, but none of these prophets, except for Isaiah who also features in Kings, belong to the 'classical' or 'writing' prophets of the Hebrew Bible, and the prophetic books known to us - probably apart of some form of Jeremiah ${ }^{52}-$ seem

${ }^{50}$ See, e.g., Steven J. Schweitzer, 'Judging a Book by Its Citations: Sources and Authority in Chronicles', in Ben Zvi and Edelman (eds.), What Was Authoritative for Chronicles?, pp. 37-75.

51 See Schniedewind, The Word of God in Transition, pp. 213-230; Beentjes, 'Constructs of Prophets and Prophecy in the Book of Chronicles', pp. 37-38.

52 See Jonker, 'The Chronicler and the Prophets: Who Were His Authoritative Sources?', and Warhurst, 'The Chronicler's Use of the Prophets'. 
not have served as sources of the Chronicles. Nonetheless, it deserves attention that the writings of the prophets are equated with 'prophecy' (נבואה) and 'visions' (תזות) in 2 Chr 9:29, hence giving them an inspired status. The world of the Chronicles is emphatically text-centered, and the book 'communicates and embodies Torah, without claiming to be Torah', 53 hence presupposing the Deuteronom(ist)ic idea of the Book of Torah as the center of the community. Moreover, in Chronicles, unlike the Deuteronomistic literature, there is a strong connection between the documentation and inspired interpretation of the past, which appears as a specifically prophetic task. ${ }^{54}$ Divination, again unlike Samuel-Kings, plays no role in Chronicles, since it seems that 'the unfolding of history is itself the omen' 55 to be interpreted.

But does Chronicles assume that the prophets actually wrote their records themselves, especially if we understand the verb כתב to refer to the textual production at large and not just the act of writing? According to Gary Knoppers, the prophets 'appear as literati, scribes who take a consistent interest in writing about the times in which they lived'. ${ }^{56}$ This statement is justified in the world of Chronicles which is a text-centered world of literati, ${ }^{57}$ and it is not difficult to imagine the authors of Chronicles to create the prophets in their own image. In the Chronicler's source refererences, the prophets truly appear as authors of the inspired interpretation of the past, hence the prophets in Chronicles can be seen as belonging to the class of 'writing prophets' - but they do not write prophetic books; instead, they write the past.

One text that does not exactly fit any of the above-discussed patterns remains to be discussed: Jer 51:59-64. Here Jeremiah is said to have written a scroll containing prophecies against Babylon, in order to be read

${ }^{53}$ Ehud Ben Zvi, 'One Size Does Not Fit All: Observations on the Different Ways that Chronicles Dealt with the Authoritative Literature of Its Time', in Ben Zvi and Edelman (eds.), What Was Authoritative for Chronicles?, pp. 13-35, esp. 27. Cf. Jonker, 'The Chronicler and the Prophets'; Erhard S. Gerstenberger, 'Prophetie in den Chronikbüchern: Jahwes Wort in zweierlei Gestalt', in Friedhelm Hartenstein et al (eds.), Schriftprophetie: Festschrift für Jörg Jeremias zum 65. Geburtstag (Neukirchen-Vluyn, 2004), pp. 351-367.

54 Cf. Knoppers, 'Democratizing Revelation?', p. 402.

55 Amit, 'The Role of Prophets and Prophecy in the Chronicler's World', p. 90.

56 Gary N. Knoppers, 1 Chronicles 10-29: A New Translation with Introduction and Commentary (AB 12A; New York, 2004), p. 958.

57 Cf. Ben Zvi, 'One Size Does Not Fit All' and idem, 'Observations on Josiah's Account in Chronicles and Implications for Reconstructing the Worldview of the Chronicler', in Yairah Amit, Ehud Ben Zvi, Israel Finkelstein, and Oded Lipschits (eds.), Essays on Ancient Israel in Its Near Eastern Context: A Tribute to Nadav Na'aman (Winona Lake, 2006), pp. 89-106. 
publicly by Seraiah the quartermaster and then thrown in the Euphrates. This text presents the prophet Jeremiah as writing a scroll - apparently by himself - and commissioning an official to act in Babylon according to his instructions. The text gives the prophet an agency and authority unheard of in the previously discussed texts. It shares features with Jeremiah 36 and may be dependent on it, ${ }^{58}$ but in 51:59-64 Jeremiah is not commissioned by God, neither does he need any help in writing the scroll. If the text corresponds to 50:1, then the scroll is probably thought of as containing the words God spoke against Babylon 'by (ביד) (MT: the prophet) Jeremiah' in chapters 50-51. These words, unlike Jeremiah 36, are not designed to be rewritten, nothing is added to them, and they are not meant to be preserved for posterity; instead, they are used as a sign portenting the destruction of Babylon. The magical and symbolic function of the text written by Jeremiah connects it with the short inscriptions in Isa 8:1 and Ezek 37:16, only this time we have to do with a large scroll containing 'all' the words concerning Babylon. The ominous nature of the text, together with the image of Jeremiah as a scribe capable of authoring such a scroll, again, bear a certain resemblance to the image of the prophets in Chronicles, the scribes writing the ominous past.

\section{CONCLUSION}

Since when do prophets write in the ancient Near Eastern sources available to us, including the Hebrew Bible? If the question refers to the act of writing according to the traditional 'writing prophets' model, the answer is: probably not before Chronicles and Jer 51:60, whatever their chronological order. ${ }^{59}$

The ancient Near Eastern and biblical sources do connect prophets with writing, and the prophetic agency sometimes implies a role in text production, hence the sources presuppose a connection between prophetic and scribal activities. ${ }^{60}$ It is evident that the prophetic process of

58 Thus, e.g., Robert P. Carroll, Jeremiah: A Commentary (OTL; London, 1986), p. 856.; Bernard Gosse, 'La malédiction contre Babylone de Jérémie 51,59-64 et les redactions du livre de Jérémie', ZAW 98 (1986), pp. 383-399. According to Gosse, Jer 51:59-64 (LXX: 28:59-64) is also inspired by Jer 25:1-13 which in the LXX is the first oracle against nations.

${ }^{59}$ In fact, I have not put much effort into dating the texts discussed above; it is not impossible that some of them actually postdate Chronicles.

${ }^{60}$ Floyd, 'The Production of Prophetic Books', p. 142: 'Various types of prophetic activity might entail direct use of writing, whether in a nonacademic setting like the cult or in 
communication sometimes included written media. However, texts other than Chronicles and, perhaps, Jer 51:60 do not seem to presuppose prophets to represent but a basic literacy, if any. In theory, it would be entirely possible that persons with scribal education could sometimes act as prophets, but this is neither reported nor presupposed by our sources. ${ }^{61}$

In the non-biblical Near Eastern sources, no single prophet can be found writing a text, probably because prophets seem not to have belonged to people of whom literacy was expected. In the Hebrew Bible, prophets do appear a few times as subjects of the verb 1) כתב Sam 10:25; Jer 32:10; 51:60; 2 Chr 26:22; Dan 7:1), of which only Jer 51:60 and 2 Chr 26:22 can be seen as implying the idea of a prophet writing a text. The cases where the prophets are explicitly told to כתב by God (Isa 8:1; 30:8; Jer 30:2; 36:2, 28; Ezek 24:2; 37:15-16; Hab 2:2) mostly belong to the very wording of the oracle and, hence, to the virtual rather than the factual world. The act of writing is not described except for the case of Jeremiah 36 where the command is fulfilled by employing Baruch the scribe to accomplish the actual writing.

Indeed, the question arises whether the verb כתב should be understood as denoting the whole process of textual production with several individuals participating in it. If 'writing' is understood in this broader meaning, there is more evidence of prophets involved in the scribal continuation of the prophetic process of communication; this evidence includes at least the letters of Yasim-El from Mari (ARM 26414 ) and the Lachish ostracon nr. 3. Biblical passages such as Isa $8: 1 ; 8: 16 ; 30: 8$ and Hab 2:2, reflect a procedure that imitates a legal act of writing and notarizing a document in the presence of witnesses, perhaps also reading it out before the public. Prophetic literacy is not an issue here; what matters more is the role of the prophet as a prophet, that is, the intermediary of divine words. All this is makes sense against the Near Eastern scribal practices that sometimes may have accompanied prophetic performances.

the context of a scribal school. And conversely, various types of scribal activity, whether in or out of an academic context, could be prophetic in the sense that documents were written and studied in order to discern divine involvement in contemporary human affairs.'

61 Karel van der Toorn leaves the door open for the possibility that Jeremiah was actually capable of writing; however, 'Jeremiah was a spiritual leader, an advisor to the king, a priest whose intercessory prayer was credited with special efficacy - but he was no literary author' ('From the Mouth of the Prophet: The Literary Fixation of Jeremiah's Prophecies in the Context of the Ancient Near East', in John Kaltner and Louis Stulman [eds.], Inspired Speech: Prophecy in the Ancient Near East, Essays in Honour of Herbert B. Huffmon [JSOTSup 378; London, 2004], pp. 191-202, esp. 201). 
The book of Jeremiah goes further in presenting itself as an edited oracle collection on its own right, as 'licensed outgrowths of Jeremiah's work' ${ }^{62}$ The self-references in Jeremiah presuppose the emergence of a new type of divinatory text, a prophetic book, which marks the transition from written to literary prophecy and, implicitly, highlights the role of scribes in the Fortschreibung of prophetic words. From now on, the class of literati has assumed the prophetic role, which, in fact, eclipses the issue of the literacy of the prophet. The prophet is credited an authorship that surpasses the commissioner-type of agency ascribed to Isaiah or Habakkuk; however, as the role of Baruch the scribe clearly demonstrates, this in no way highlights the literacy of the prophet but, rather, the agency of the scribes in the prophetic process of communication.

In the book of Ezekiel, the prophet is deprived of authorship altogether by making him the recipient of the divinely written scroll. Here the prophetic process of communication takes a new, scribal turn whereby the agency of the prophet with regard to writing is understood in a way different from the Near Eastern sources, and also from Jeremiah: the text itself becomes an authority related to the authority of the Torah. In Chronicles, finally, the scribalization of prophecy has reached the point where visions and prophecies are referred to as scribal products, and prophets have become their authors. These books are presented as inspired historywriting, interpreting the omen constituted by the past itself.

${ }^{62}$ Leuchter, The Polemics of Exile, p. 107. 